\title{
7. Facilitated news as controlled information flows: The origins, rationale and dilemmas of 'embedded' journalism.
}

\section{ABSIRACI}

The article traces the origins, rationale and some of the dilemmas that have emerged in the practice of 'embedded' journalism. It argues that the practice emerged as a post-Vietnam response by the US military to the 'problem' of independent news coverage of conflicts in which the US was involved. For the post-Vietnam US military, independent news coverage was problematic because it often contradicts the official war narrative and, if left unhindered, undermines public support for the war effort. Since public support is crucial for success in a foreign war, particularly during lengthy engagements, independent news coverage is seen as a threat to the unity of the home front and therefore a threat to the war effort itself. The lesson learned from Vietnam was to restrict independent media access to battle zones, first by denying all access and withdrawing security guarantees to journalists operating in conflict theatres, and then by providing privileged but controlled access to front line units via the practice of facilitated news-gathering known as 'embedded journalism'. As it turns out, even that practice has a downside, and there is more to the story than the military desire to control the narrative.

Keywords: conflict reporting, embedded journalism, facilitated news, independent news, objectivity, propaganda, war correspondence

PAUL G. BUCHANAN

Security analyst, Auckland 
7 HE RESPONSE to the 'problem' of independent news gathering in conflict zones in which the US military was engaged was first elaborated during the Reagan administration. It was honed and perfected in different ways during subsequent decades of fighting by Democratic and Republican governments, but the overall trend was towards increased control of information flows. What they have in common is the break with past journalistic practice. Historically, military correspondents are soldiers, representatives of major news outlets or independent stringers. Although the specifics have varied, the first are uniformed personnel who report in the military press or who act as 'in house' correspondents for commerical media, the second are accredited reporters with access to military briefings and movements, and the third are unaffiliated individuals who follow and sometimes accompany troops into battle but are not permanently attached to any particular unit or news agency.

Embedded journalists are something else. They are media figures that have received an explicit invitation to join troops on a cohabitating basis for relatively extended periods of time. They live, patrol and often come under fire with the units that they are assigned to, so that, the argument goes, they may better understand the totality of the soldiering experience in a foreign combat zone (Pfau et. al., 2004, pp. 74-76).

That privileged access comes at a price, and that price is not written in any press guidance issued by the US Department of Defense or other militaries that have adopted the practice. Embedded journalists are often selected based upon the relationship their media employer has with the inviting government or the military as well as their individual propensity to support 'the troops' whom they depend on for their care and welfare while in combat zones. The relationship is symbiotic. Embedded media get access to front and back line action while the military gets a sympathetic public depiction of its endeavours. Current media industry practices facilitate the use of controlled news sourcing by focusing on the embedded reporter's story and those of the troops with which the reporter is embedded rather than the military context in which they operate. The reporter becomes both protagonist and narrator in the ultimate reality show. The terms and conditions to which the embedded reporters agree preclude critical scrutiny of potentially negative impact of the combat experience on innocents and ensure that the journalistic narrative conforms to the military's preferred interpretation of events. In effect, there are both push and 
pull factors at play in the rise of embedded journalism: the military pull to control the news flow at the same time that there is a push for ratings-driven reality programming in the corporate news media.

Withdrawal of security guarantees for independent journalists and termination without warning of embedded status for reporters who violate the terms and conditions of the facilitated news contract provide strong physical disincentives to engage in non-sanctioned and uncontrolled reporting in combat zones. For example, in 2004 the 'embed' credentials of two Virginia-based journalists were revoked because they photographed and ran a story about a bullet-ridden Humvee they had seen in Kuwait. This effectively left them defenceless in a war zone where they had no local contacts or alternative security provision. The dangers of embedding exist even with security guarantees in place, and serve a useful purpose for the facilitating entity. A contrary incident such as an embedded reporter's or accompanying soldier's death or injury suits the military narrative as to the unsavoury character of the adversary and the risks to the soldiers involved in fighting the 'good' fight (such as bringing freedom to oppressed people against their will). Sympathetic and de-contextualised coverage of contrary events serve to make real the immediate costs to the 'good' team and re-emphasises the need for public support for their sacrifice in what otherwise might seen as a distant and seemingly inconsequential, meaningless or futile conflict (since no modern conflict involving the US has seen its core national security interests at stake). Strategic breadth is sacrificed in order to achieve tactical depth and immediacy in reporting (Cockburn, 2010).

Facilitated news provision such as that embodied in the concept of embedded journalism can serve propaganda purposes - and often is no more than that - but it is not reducible to it. Propaganda is the direct transmission of ideologically supportive messages from the State to target audiences (both domestic and foreign). Here there is an intervening variable - the embedded journalist, presenting war from his or her personal perspective. For similar reasons embedded journalists are more than mere public relations (PR) flacks. A better way to look at embedded reporting is as a weapon in the information war that runs parallel to combat. As a US military spokeman phrased it, 'Frankly, our job is to win the war. Part of that is information warfare. So we are going to attempt to dominate the information environment. Embedding journalists honorably served that end' (Kahn, 2004). 
As part of its information warfare strategy (itself a component part of larger psychological operations (PSYOPS) campaigns), the military may use journalists as third party transmission belts, amplifiers or echo chambers for the State-supportive message, where the message remains unaltered by the messenger. But embedded journalists are free to write the specific narrative for the events they are covering, using as a general guideline the unwritten understandings and formal protocols undertaken in order to secure the embedded assignment. Within those formal and informal guidelines the reporter can emphasise aspects of the story as he or she sees fit so long as it conforms to the broad objectives of the military command and the rules of engagement governing the embedding process. In this sense they act not so much as direct transmission belts for State ideology or PR agents but more as what Lenin referred to as 'useful fools' of the military apparatus: wellmeaning and sympathetic actors that disguise the controlled or manipulated aspect of the embedded perspective by interjecting their own thoughts and words into the story line.

The beauty of embedded journalism is in the synergies produced by the overlapping interests of security forces and news outlets: each gets to convey its own particular message of legitimate effort and real-time involvement in mutually reinforcing fashion without delving into the circumstances and ethics involved in the larger context into which journalists are embedded. The reporter burnishes his credentials as a war correspondent, the media employer reaffirms its privileged access to sources of power and the military frames the representation of conflict in narrowly constructed, sympathetic terms (Ricchiardi, 2003). The audience is entertained while empathising with the plight of the troops and reaffirming its loathing of an enemy abroad that seeks to do them harm (even if that enemy is fighting on its own soil in defence of its sovereignty and national identity). In this fashion the war narrative is controlled, contrived, manipulated and sanitised in the interests of corporate and governmental elites far removed from the conflicts in which the 'reporting' occurs.

\section{A brief history of facilitated newsgathering in modern US warfare}

The Vietnam War taught the US many lessons, but the lessons learned were not necessarily those that one might suspect. Rather than recognise the advantages the irregular combatant has when waging protracted guerrilla warfare on home soil, the US military learned that its technological 
superiority in weaponry and long-distance logistics was fatally undermined by a lack of popular support at home. Instead of re-examining its approach to unconventional warfare as both a kinetic and political exercise and the rationales behind 'asymmetric' combat that negated technological superiority in the irregular battle space, the post-1975 US military determined that a major source of popular discontent with the war was independent journalists, particularly video journalists, reporting on aspects of conflict that were unflattering to the US military or which cast the military effort in a negative light. The photographs of the napalm bombing of Trang Bang and reporting of the Mai Lai massacre (both of which won Pulitzer Prizes for Journalism) were used as examples of how such unfettered reporting undermined troop morale and popular support by casting the US military as villains rather than as saviours. In addition, this type of reporting during the 1968 Tet offensive contributed to the decision by Walter Cronkite, then the US's pre-eminent television news anchor, to announce on a primetime national newscast that the war was lost (even though the Tet offensive was a tactical victory for the US and South Vietnamese), something that expanded domestic opposition to the war beyond its radical youth origins.

The immediate solution to the problem of independent journalism was to exclude it. War zones are dangerous places, so the US military adopted a policy in the 1980s of not guaranteeing journalists' safety in combat zones, even if these were behind front lines. This included accredited journalists and independent 'stringers'. Instead, they were advised to steer clear of direct reporting of front-line combat and to attend briefings hosted by the military commands involved. This is a practice long familiar to correspondents who understand the vicissitudes of the front lines (that is, bullets can fly anywhere) and therefore prefer to report on what the military command provides in the way of after-action reports and battlefield summaries. During the 1982-83 Lebanon conflict, the 1988 invasion of Granada, the 1989 invasion of Panama, the 1991 Gulf War, the 1993-94 Haiti intervention and the 2001 invasion of Afghanistan, the US military informed news outlets that it could not provide them with security and hence access to conflict zones (Zeide, 2005, p. 1314). Active duty (uniformed) photographers and correspondents covered the action from within assigned military units while civilian journalists were left to rely on military briefings away from the front lines or on staged tours of them, on second hand reports from civilians or soldiers after the fact, 
or to risk unauthorised forays into combat zones in which they could well be misidentified as 'hostiles' by US forces.

Amid questions about the constitutionality of the exclusion orders, major US news outlets complained about the lack of access even as foreign independent journalists assumed the risks historically associated with war correspondence and reported directly from the field without the benefit of US military protection (this was less true of Grenada and Panama, where the US was able to prevent independent journalists from entering the countries after the initial invasion). Yet in a perverse way the dangers of independent reporting, coupled with the denial of access to US military units involved in combat, set the stage for the practice of journalistic embedding in military units (some call it 'imbedding', as 'in bed with'). The concept of preferential but controlled media access developed in parallel to another journalistic development, which when combined with media demands for battlefield access and technological innovations transformed into the practice of embedded journalism.

During the 1990s, US journalists were granted increased access to political campaigns and elected officials. Presidential press conferences increased in frequency, reporters travelled with candidates during their campaigns rather than report from selected stops along the way, C-Span was launched and flourished. This 'real-time' form of political reporting proved very profitable for media outlets, which could demonstrate their access and ability to shape a candidate's or politician's image based upon the extent and type of such access. Candidates, in turn, saw value in presenting themselves as 'real' people in 'unguarded' moments, so both sides benefitted from the arrangement.

Developments in the media world also shaped the approach to war correspondents. In the late 1970s, as Rupert Murdoch extended his media holdings into the US with the launch of the first Fox channel, the concept of 'reality TV' began to dominate television ratings. Starting with the still-running show Cops, in which TV crews accompany local police on patrols in dozens of US cities, passing through a variety of MTV 'reality' shows and moving to entire channels dedicated to reality (some might call it voyeur) programming such as True $T V$ and the appropriately named Escandalo (Scandal) $T V$ for Hispanic audiences, the US television medium has become dominated by seemingly non-scripted or lightly scripted shows featuring 'real' people doing 'real' things, some of which are actually live or real-time in nature. Not surprisingly, with growing popular demand for 'reality' came media interest in showing the 
reality of conflict on a real-time, first person, 'raw' basis. Yet with regard to war coverage, the standing post-Vietnam rules governing journalistic access to the US military engaged in conflict zones ran directly counter to such a project, and instead promoted highly scripted second-hand, time delayed and heavily filtered military descriptions of events (the classic instances of this being the coverage of the liberation of Kuwait in 1991, which was essentially stage-managed by the US Central Command and Department of Defense).

The growth of internet-based news collection compounded the push of reality programming on corporate news organisations. As internet-based sources of information grew and published unvarnished accounts of pretty much anything (some factual, some not), corporate print and television ratings declined as audiences shifted their preferences to the 'new' media, many of which ran stories that did not conform to governmental or corporate dictates. This shift in audience preferences ran along generational lines, with youth leading the move to new media technologies. That foresaw an inevitable negative effect on corporate media profits as youth looked elsewhere for 'raw' news and as adults continued to use those alternative sources as the mainstays of their personal information stream.

Faced with the downturn in audience and readership numbers, corporate media began to adopt some of the alternative news dissemination formats such as web logs. But the major response was to cut the number of dedicated reporters assigned to specific subject areas such as war correspondence, as this was the easiest managerial solution to the declining rate of news-derived profit.

Many of those made redundant were the most experienced (and hence expensive) journalists in corporate media stables, who were replaced by inexperienced and often non-journalist 'talking heads' whose role was to look good, become famous and therefore add reality 'bite' to whatever story line they were covering. The trouble was that the new type reporters often had no understanding of warfare or were reluctant to engage the personal risks involved in genuine war correspondence. Hence the invitation to embed with military units provided them with an opportunity to enhance their following while seemingly developing an understanding of combat without facing the risks of independent journalists (even if the embedding situation offered more of a false sense of security rather than an absolute guarantee of it). In effect, facilitated access was granted not so much on prior credentials but on the basis of who reporters worked for, which suited the interests of the military, corporate media managers and individual journalists involved.

108 PACIFIC JOURNALISM REVIEW 17 (1) 2011 
Confronted by pressures to relax its 'no access' rule in a downsized corporate media climate that increasingly relied on reality programming for profits and celebrity reporting of news, the Pentagon began to consider alternative ways of facilitating news coverage that would not undermine military missions or popular support for them. This complemented ongoing US military cooperation with Hollywood, where movies such as Top Gun and Clear and Present Danger proved mutually profitable for studios and military recruiting alike. The military wanted to extend this good working relationship to other mediums, and embedding journalists from major news media outlets is a good way of doing so.

Trial runs using reporters travelling with US military units in the 1991 Gulf War proved very good as a form of public relations exercise, leading to the controlled inclusion of reporters along with US military and Coast Guard units undertaking low-intensity conflict tasks such as anti-narcotics operations and drug interdiction missions. The early experience with embedding reporters was positive from a military standpoint, as the coverage of the military operations against identifiable and unqualified enemies (such as drug dealers or Saddam Hussein) was generally favourable. Embedded journalists did appear to gain a better understanding of the reality of military life and achieved better depth of knowledge of what military operations, if not actual combat, entailed. To this was added the positive experience of embedded reporters during the Falklands War, where British correspondents reporting alongside (and completely dependent on) their troops developed close attachments to the units to which they were seconded, thereby contributing to positive coverage of the re-conquest of the islands (Misker et. al., 2003, p. 9).

Improvements in telecommunications technologies and miniaturisation of audio-visual equipment also made it easier for journalists to report directly from the field, lessening their dependence on support crews and fixed logistics lines. This played into the equation: A reporter, his or her cameras and computer, and a military unit = direct information from the battle zone (although on any given day battlefield reporting still remains subject to home office editorial whims that may favour celebrity scandal over bloodshed in a foreign country).

The military can argue with justification that the evolution of warfare from fixed line, conventional front engagements to more amorphous 'shadow' conflicts involving irregular combatants and unconventional tactics, coupled with the increased lethality of both high and low technology weaponry, made 
INVESTIGATIVE JOURNALISM

it essential for their own safety that journalists embed with military units. This turned out to be true in both Iraq and Afghanistan, where kidnappings and killings of foreign journalists by insurgent forces became standard practice. By agreeing to the quid pro quo involved in the construct (safety for sympathy), embedded journalists increased their rapport with the troops and commanders who facilitated their reporting, thereby opening doors to ongoing commandlevel briefings and one-on-one interviews with senior military figures. Even so, the facilitation of news coverage via embedded journalism was limited in the latter 1990s to low-risk environments rather than serious combat. This precluded real-time coverage of US military operations in places like Somalia (of Blackhawk Down fame), in Latin America (in counter-insurgency operations) or special operations against Serbian forces in Kosovo or Bosnia-Herzegovina.

The practice of limiting independent journalist access to US forces in combat continued after 9/11 and the invasion of Afghanistan. Early coverage of the fight against the Taliban was notable because of the lack of US-based reporting of it, with an array of non-US journalists (including at least one New Zealander) risking life and limb to cover key moments in the struggle such as the siege at Mazer e-Sharif and the bombing of Tora Bora.

By 2003, the long build-up to the invasion of Iraq brought with it a comprehensive programme for embedding journalists in US military units. Crafted by Pentagon comunications chief and former public relations executive Victoria Clark, guidelines were drawn up by the Central Command (the military command responsible for the Middle East and Central Asia) and approved by the Office of the Secretary of Defense in what became official US policy (US Secretary of Defense, 2003). Given its ideological predilections and support for the George W. Bush administration, Fox News was given pride of place in the embedding process, with such as retired USMC Lt. Colonel (and Iran-Contra conspirator) Oliver North and muckraker Geraldo Rivera being granted plumb assignments in the run into Baghdad. Concerned about being at a competitive disadvantage vis a vis Fox and operating under the same 'celebrity reporter walking the walk' model, other cable, network and print news outlets agreed to the terms and conditions imposed on their coverage of the conflict in exchange for embedded access as well. To date, more than 750 journalists have been embedded with US military units in Iraq. That in turn has led to the use of embedded reporters in Afghanistan (Cockburn, 2010), to the point that in some journalistic circles the country became known as 'Embedistan' (Farrell, 2010). Not surprisingly, embedding-type practices

110 PACIFIC JOURNALISM REVIEW 17 (1) 2011 
were adopted by US military partners such as the UK and Australia (the term 'embedding-type' refers to short-term journalistic assignment into a specific military unit in the field rather than longer-term cohabitation arrangement. It is also different from one-off spot visits or military briefings). In one form or another, by the end of the first decade of the millennium, embedded journalism has become a standard feature in the media approach to covering war.

\section{Embedded reporting as Trojan Horse}

There was bound to be unanticipated synthesis emerging from the action-reaction, thesis and antithesis relationship between the military and embedded journalists. The relationship evolved, but not in the controlled fashion that the military would have hoped. Specifically, as the media and the military became more comfortable with the practice of embedding journalists in military units, a curious role change occurred. Rather than an instrument employed by the military to get its favoured message across, embedded journalism became a potential 'enemy' within. This was the result of changing attitudes on the part of the military and the press corps as conflicts continued and home audience preferences changed. The result has been something other than the original intention of framing the narrative.

The success of the original embedding project during the 2003 Iraq invasion and occupation encouraged the military to expand the reach of facilitated news provision. Content analysis of embedded versus nonembedded reporting confirmed that embedded journalists were more likely to present favourable interpretations of military activities and the soldiers that they served with (Robbe, 2010). Yet, by 2007 the American public had begun to lose interest in war stories. This was in part due to impatience and frustration on the part of the US public as months turned to years of engagement without clear victory in sight in both Iraq and Afghanistan. Given the myriad distractions provided by American popular culture and the dislocating effects of economic recession on public interest in military engagements abroad, by 2008 the US military sought to move beyond the now routine coverage of infantry and armoured tactical patrols and human interest stories and into command centres in which strategic decision-making occurred.

Such was the case with the US Afghanistan command, where General Stanley McChrystal and General David Petraeus (who also permitted embedded reporters in the Iraq military command) allowed facilitated news gathers to report from inside their command headquarters. The idea behind the 
expansion 'upwards' of embedded news coverage from tactical operations to theatre and strategic policy-making was to demonstrate to the American public the complexity and extent of this new form of 'asymmetric' warfare in which the enemy fought and hid amongst civilian populations who were not entirely supportive of the international effort to free them from local despotism and in which a multiplicity of other national and international actors were involved.

The logic of the US military decision to 'upscale' the embedding process was simple: for an American public increasingly disinterested in the wars and disillusioned about the lack of progress towards a concrete victory in them, embedded reporting from the command headquarters involved in those conflicts would shed light on the intricacy of the situation as well as the need to continue to be steadfast in pursuit of a favourable outcome. Thus the narrative shifted from the 'grunt' level perspective of the soldier on patrol to the strategic logic of the generals who understood that the US had to continue its war missions for larger reasons beyond finding Osama bin Laden ${ }^{1}$ and killing terroristsissues that included matters of international reputation, alliance commitment, deterrence, and other geopolitical and strategic concerns. With the facilitated move upwards, embedded reporters are now privy to the bigger picture and the broader contours of the multi-layered game that is international conflict.

The trouble for the US military is that removing embedded reporters from the battlefield where their personal security rests in the hands of the soldiers with whom they travel and moving them to secure command headquarters where both their creature comforts and security are assured by the more benign kinetic environment and layers of security surrounding the command, serve to loosen the physical dependence of embedded journalists on the military units to which they are attached. Even while on front line duty many embedded journalists began to interview troops from units to which they were not attached simply in search of a fresh story line, in semi-independent fashion. This situation was compounded by the fact that just as the American public and the corporate media began to lose interest in tactical-level embedding other media outlets requested embedded status, including some with alternative perspectives on matters of government policy such as the Public Broadcasting System, Pacifica News Network and Rolling Stone Magazine.

With broader media access to the embedding process and with looser physical security ties between soldiers and reporters at the command level, and given the debates over foreign military policy dividing the US political elite and public throughout the early 2000s, the stage was set for 
embedded journalism to become the Trojan Horse of US military campaigns. That occurred in 2010, when Rolling Stone reporter Michael Hastings published a story about General McChrystal and his command staff detailing how they were deeply critical of, if not insubordinate to, President Obama, Vice-President Biden and some of their closest advisers (Hastings, 2010). The uproar that ensued was fatal to General McChrystal's career and seriously undermined the Obama administration's attempts to convey a unified and coherent approach to national security affairs.

Although General McChrystal resigned and General Petraeus accepted a demotion in order to replace him as Commander-in-Chief of US forces in Afghanistan, the damage was done at several levels. The Rolling Stone story detailed deep policy divisions and personal disrespect between members of the military hierarchy and civilian command authority as well as basic uncertainty among all of them about the progress of the war effort in Afghanistan. These revelations were in turn noted by US allies in the UN-mandated and NATOled International Security Assistance Force (ISAF) fighting in Afghanistan, with the resultant loss of support undermining allied commitment to continuing their engagement with the US-led ISAF coalition. To that was added the oft-times unflattering commentary of troops in the field to other embedded reporters regarding the local population and the Afghan national leadership. Eager to press the news cycle envelope in the quest for ratings and wishing to capitalise on the deep political divisions extant at home for partisan purposes, even 'loyal' American reporters began to deviate from the military's preferred narrative. This posed a serious dilemma for the US military, as it had come to depend on embedded journalism as an antidote and counter-weight to critical reporting of US military activities from independent and mostly foreign journalists and media organisations, including the Russia Today (RT) network, the $\mathrm{BBC}$, an assortment of European media sources, Al Jazeera and the WikiLeaks organisation (which has its own version of embedded reporters in the form of disgruntled US military personnel leaking classified information to it).

Beyond arguments about whether the quoted conversations were on or off the record, the important thing to note about the McChrystal/Rolling Stone story is that Hastings did not violate the guidelines and policies for embedded journalists issued by the Central Command and Department of Defense in 2003. To the contrary, he reported on issues that had nothing to do with combat per se and all to do with the relationships and dispositions of those in flag-level field billets and their superiors in Washington DC. 
The conventions and protocols established in 2003 for the embedding of journalists did not cover such reporting options because it presumed that acceptance of the embedding conditions operative at the tactical level translated into journalistic 'loyalty' to the military units involved even if the focus of coverage moved to the command level. In the current media climate, that was a stretch too far. Not surprisingly, in August 2010 Hastings had his 'embed' credentials revoked by the US Department of Defense (Greenwald, 2010).

The US military now sits on the horns of a dilemma: it needs embedded journalists to convey its preferred message, but it can no longer rely on them to faithfully do so. Moreover, other militaries have used journalists to convey their own messages, not all of which accord with that of the US (for example, the NZDF prefers to use journalists to emphasise the humanitarian aspects of their involvement in ISAF rather than the fact that some of the NZDF assets deployed in Afghanistan - the SAS in particular - are there to kill and deter Taliban and al-Qaeda militants. This detracts from the US message that the main ISAF objective is not nation-building and the promotion of human rights but to defeat the Taliban and prevent Afghanistan from becoming a safe haven for al-Qaeda). To that can be added the return of independent journalists (again, mostly non-US citizens) to difficult-to-control battle spaces such as in Afghanistan, which unlike Iraq cannot be easily ring-fenced or cordoned off using land and air power given the nature of the terrain. This means that the US military is more or less back to square one when it comes to controlling the message about the conflicts in which it is engaged (this is less so for special operations missions in places like Yemen or Pakistan, which are highly secret and conducted in conditions of extreme danger, thereby diminishing the likelihood of any real time press coverage).

\section{Where corporate media and military interests overlap and diverge}

In the early days of embedded journalism corporate media and military interests overlapped. Corporate media saw a profitable return on its investment in embedded journalism and the US military saw a positive spin given to its combat operations. But as time drew on and audience preferences gravitated to the likes of The Amazing Race and Jersey Shore, the quest for ratingsdriven profit, counterpoised against the need to maintain public support for US military operations abroad, forced a divergence in perspectives between the US military and the corporate media. Sympathetic war reporting was increasingly seen by the US public as boring if not mere propaganda. It was 
no longer 'fresh'. In a US political climate of deep partisan division, corporate media managers increasingly turned to 'edgy' stories that had a critical perspective on war and its consequences so as to maintain falling reader and viewership ratings. Some of it is quite partisan and anti-US - witness RT coverage of any US military operations, al-Jazeera coverage of US policy in the Muslim world, including its military engagement with it, and the thrust of WikiLeaks document 'dumps' — but much critical reporting on US military operations is done by US and allied media agencies and citizens with no particular ideological or nationalistic axe to grind.

As a result, the US military has learned the hard way what others already knew: that money is made by ratings, and ratings are made by providing news that is 'fresh'. So long as military and media interests overlapped - that is, the media made money providing sympathetic coverage of military operations - then all was well. But as soon as audiences tired of the sympathetic, narrow tactical-level view of war and ratings for such news began to drop, then the interests of the military and media began to diverge. The US military thought best to go strategic with embedded reporting in order to sell the public on the stakes and complexities involved in conflict zones like Afghanistan. For the corporate media, the answer to audience disinterest was not just to accept the move into command-level embedding (which it was happy to do). It was also to resume critical reporting in order to regain the 'edgy' perspective that drove ratings and readership under the banner of press freedom. Under such conditions having embedded journalists 'go strategic' made the problem of uncontrolled reporting worse, not better.

\section{Conclusion}

As a type of news-gathering exercise, embedded journalism appears to be here to stay. Originally facilitated with the purpose of framing the narrative emerging from battle zones in light of the negative impact independent journalism had on US public support for war, over the last decade it has taken on a life of its own driven by profit-oriented corporate media logics and a general tendency by news-gathering entities to no longer submit to being manipulated in overt ways. Even if not universally accepted, editorial independence within the embedded context is being asserted in a measure that the US military did not foresee when it enunciated its formal guidelines and policies for embedding in 2003. Efforts to expand the embedding practice to the command level backfired with revelations of command-level discord 
even while US public attention continues to drift away from war coverage in general (one of the remarkable aspects of the November 2010 US midterm elections was that debate over US military operations in Afghanistan, Iraq and elsewhere were virtually non-existent, having been eclipsed by arguments about taxation, federal deficit spending, illegal immigration and changing cultural mores). In sum, embedded journalism evolved from an instrument of military control to a double-edged sword once ratings-driven media logics argued in favour of a move away from sympathetic and narrow tactical coverage. Moving the focus of embedded scrutiny up the chain of command only worsened the conundrum.

It is difficult to predict how the practice of embedded journalism will evolve. It may be discontinued and replaced with the usual PR junkets into military zones and a return to more 'old school' non-embedded war correspondence. But it more likely will survive as a journalistic practice, in more than one guise. One potential scenario is that it will bifurcate into two streams: one an instrumental $\mathrm{PR} /$ propaganda stream in which militaries use sycophantic reporters or celebrities - comedians are very good for this purpose, as Bob Hope's Vietnam ASO tours proved even if the war was ultimately lost - as tools in order to transmit a controlled and contrived message about their operations within a specific news cycle. There could also be a second critical stream in which, with a mind towards the historical record, military commanders permit journalists to report freely (within the limits of operational security) from within designated units over extended periods of time. This stream will be truthful but perhaps time-delayed so as to protect both the guilty and the innocent.

Both streams will depend on government approval, and that in turn hinges on government agreement in principle with the notions of a free press acting as a critic and conscience of society. Since many nations continue to be ruled by authoritarians of various stripes and many democracies, new and old, are suffering from various forms of institutional sclerosis, ethical decay, lack of accountability, corruption, apathy, commodity fetishism and other maladies, it will not be surprising if the first stream dominates the latter, or that a return to the practice of denying facilitated press access to the battlefield is seen by States as the preferred method for dealing with news-gathering in a combat environment. The answer ultimately lies in public demand for journalistic objectivity and an honest media focus on government accountability in war as well as peace.

116 PACIFIC JOURNALISM REVIEW 17 (1) 2011 


\section{Note}

1. From 2001 to 2011, Osama bin Laden was the major target of the so-called War on Terror. On 2 May 2011, he was shot dead inside a walled compound in Abbottabad, Pakistan, by US Navy Seals on a secret mission.

\section{References}

Brightman, C. (2003, March 17). In bed with the Pentagon, The Nation, pp. 1-3.

Cockburn, P. (2010, November 23) The dangers of embedded journalism, Counterpunch. Retrieved on 25 November 2010, from www.counterpunch.org/coc kburn/11232010.html

Donnelly, M, Gettle, M., Scott, G., and War, D. (2003). Embedded journalism: How war is viewed differently from the frontlines versus the sidelines. Department of Defense Joint Course in Communication, Department of Communication, University of Oklahoma. Retrieved on 15 November 2010, from www.ou.edu/deptcomm/ dodjcc/groups/03D1/INDEX.htm

Farrell, S. (2010, June 25), Embedistan. New York Times On Line. Retrieved 10 April 2011, from http://atwar.blogs.nytimes.com/2010/06/25/embedistan-2/

Greenwald. G. (2010, August 4). Michael Hastings' embed permission is revoked. Salon. Retrieved on 9 April 2011, from www.salon.com/news/opinion/glenn_greenwald/2010/08/04/hastings

Hastings, M. (2010, July 8-22). The runaway general. Rolling Stone, 1108/1109. Retrieved on 9 April 2011. www.rollingstone.com/politics/news/the-runawaygeneral-20100622

Ignatius, D. (2010, May 2). The danger of embedded journalism, in war and politics, The Washington Post. Retrieved 18 November 2010, from www.washingtonpost. com/wp-dyn/content/article/2010/04/30/AR2010043001100.html

Kahn, J. (2004, March 18). Postmortem: Iraq war media coverage dazzled but it also obscured. UCBerkeley News. Retrieved on 9 April 2011, from www.berkeley.edu/ news/media/releases/2004/03/18 iraqmedia.shtml

Miskin, S., Rayner, L., and Lalic, M. (2003, March 24). Media under fire: Reporting conflict in Iraq, Current Issues Brief Index, Department of the Parliamentary Library, Parliament of Australia (pp. 1-26). Retrieved on 20 November 2010, from www.aph.gov.au/library/pubs/ CIB/2002=03/03bib21.htm

Pfau, M., Haigh, M., Gettle, M., Donnelly, M., Scott, G., Warr, D., and Wittenberg, E. (2004). Embedding journalists in military combat units: Impact on newspaper story frames and tone. Journalism and Mass Communication Quarterly, 81(1) (Spring), 74-88.

Ricchiardi, S. (2003). Close to the action: after being shut out in previous wars, journalists had extraordinary access to the fighting in-Iraq. While not without downsides, the Pentagon's embedding plan paid big coverage dividends. American Journalism Review, 25(3) (May), 28-35.

Robbe, A. (2011, March 19).The embedded war journalism controversy: War news coverage perspectives by embedded versus non-embedded journalists [Internet]. Version 9. Knol. Retrieved on 9 April 2011, from http://knol.google.com/k/adrianrobbe/the-embedded-war-journalism-controversy/2ar0j9fkv4m0g/4 
US Secretary of Defense (2003, February 3). Public affairs guidance (PAG) on embedding media during possible future operations/deployments in the US Central Commands (CENTCOM) Area of Responsibility (AOR). United States Secretary of Defense Message 101900Z FEB 03, 2003. Retrieved on 25 November 2010, from www.defenselink.mil/news/Feb2003/d20030228pag.pdf.

Zeide, E.J. (2005). In bed with the military: First Amendment implications of embeded journalism. New York University Law Review, 80(4), 1309-1343.

Paul G. Buchanan is the principal of Buchanan Stategic Adivors Ltd., a New Zealand-based political risk, market intelligence and strategic assessment consultancy. The author of three books and more than 50 scholarly articles, chapters, monographs and reviews, he has worked and consulted for several US security agencies, and has held several academic appointments, including at the University of Arizona, University of Auckland, University of Chile and the National University of Singapore.

paulgbuchanan@gmail.com

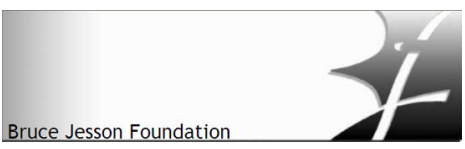

BRUCE JESSON FOUNDATION

The Bruce Jesson Foundation presents two awards annually for critical, informed, analytical and creative journalism or writing which will contribute to public debate in New Zealand on an important issue or issues:

\section{Bruce Jesson Journalist Award: $\$ 4000$}

This award is paid in advance to fund the time and costs required for an investigative project. Criteria for the award are non-political and nonsectarian.

\section{Emerging Journalist Award: \$1000}

This award is paid for already-published work by a print journalism student nominated by the country's journalism programme leaders.

Full criteria details and application forms are at: www.brucejesson.com Deadline: 31 August 2011 